\title{
Integrated Management of Leaf Curl Virus in Tomato on Farmers, Fields at Hathras District of Uttar Pradesh
}

\author{
S.R. Singh ${ }^{1}$ and S.K. Singh ${ }^{2}$ \\ ${ }^{1}$ CSAUA\&T, Krishi Vigyan Kendra, Hathras (U.P.), India \\ ${ }^{2} \mathrm{CCR}(\mathrm{PG})$, College, Muzffarnagar, (U.P.), India
}

Received: 20 October 2020/Accepted: 25 November 2020

URL:https://doi.org/10.38112/agw.2020.v08i02.005

\begin{abstract}
Tomato leaf curl virus and low yield potential diseases susceptible varieties, indiscriminate use of insecticides for leaf curl virus management are the major limiting factors, which cause substantial yield loss in tomato. Present investigation on resistant varieties having higher potential with integrated disease management proven technologies reveled that tomato higher yield could be achieved by adopting these technologies. Among the technologies, the highest yield and net return and less leaf curl virus incidence was found in technology-3, Arka Ananya+ raise Marigold (tall African variety golden age bearing yellow and orange flowers) nursery 15-20 days before tomato nursery+ One week after germination of seeds, spray the seedlings with (Imidacloprid 200 SL@0.3 ml/1 or Thiomethoxam 25 WP@0.3 $\mathrm{g} / \mathrm{l}$ )+Apply Neem cake $250 \mathrm{~kg} / \mathrm{ha}$ ridges at the time of preparing land+ Dip the roots of seedlings (do not dip the foliage as it may cause burning of leaves) with Imidacloprid 200 SL@ 0.3 ml/1 or Thiomethoxam 25 WP@ @ $0.3 \mathrm{~g} / 1$ for 5 minutes. Fifteen days after planting spray Imidacloprid 200 SL@0.4ml/1 or Thiomethoxam 25 WP@0.3g/1 for leaf curl vector (whitefly) control+ Destroy leaf curl and other virus affected plants as soon as the symptoms appear in a few plants to minimize their spread followed by technology-2 as compared to farmers' practices.
\end{abstract}

\section{Introduction}

Tomato (Lycopersicom esculentum Mill.) is one of the most popular and widely grown vegetable crops of India. In India, it occupies an area of about 8.79 lakh hectares producing over 182.3 lakh tonnes with the productivity of 20.7 tonns/ha. In Uttar Pradesh, the crop is cultivating to an extent of 91.27 thousand hectares with a production of 19.57 lakh tones and productivity of 21.4 tons/ha. (Anon., 2013). Mahamaya Nagar district situated in south western semi-arid eco-system (Zone - IV) of U.P. There are 4sub-divisions and seven development blocks in district. The small and marginal farmers are growing tomato, cucurbits, brinjal and onion as main vegetables crops of the area. Although area (570 ha), with an annual production 2565 tones and productivity $450 \mathrm{q} / \mathrm{ha}$ under tomato crop is suffering from large number of diseases. Among them leaf curl virus complex caused by tomato leaf curl begomovirus and its vector whitefly (Bemisia tabaci) is the major limiting factors, which cause substantial yield loss in India and worldwide (Sastry and Singh, 1973; Muniyappa, 1980, Muniyappa and Veeresh, 1984; Saikia and Muniyappa, 1989; Harrison et al., 1991and Muniyappa et al 2000).
Tomato cannot be grown in plains during June-October owing to high temperature and stagnation of water in fields during rainy season. But, it can be grown successfully under rain fed conditions in well drained soils of the undulating terrain. Thus, sloppy lands and precipitation mainly received during June to September provide congenial conditions for growing rainy season tomato in certain areas and it can be a boon in supplementing the income of small and marginal farmers of the regions. Though rainy season tomato cultivation is becoming increasingly attractive for cash generation in the undulating terrain of this agro climatic zone, but, the productivity of crop is very low due to several production problems like high mortality of seedlings at nursery stage, high incidence of leaf curl virus, early and late blight diseases and non availability of suitable varieties and insectides for the rainy season, thus, limiting tomato cultivation on a commercial scale. Kallo et al., (1998).

While assessment of integrated modules (IDM) for management of leaf curl virus of tomato with promising cultivars for rainy season in terms of good yield and comparatively less damage from leaf curl virus. Uses of 
tolerant/ resistant varieties for effective management of leaf curl virus disease for rainy season production. Though there are many reports on varietal selection, appropriate time of planting and leaf curl virus disease management measures for rainy season tomato, these constraints still prevail in the farmer's field. For promoting rainy season tomato production as a remunerative enterprise in the undulating terrain, availability of varieties tolerant to heat, rains and leaf curl virus has became major constraint. Majority of tomato growers purchase tomato seeds from the market with no certainty of good performance. To provide alternative option of IDM suitable modules to the vegetable growers, the experiment was conducted to assessment of different proven technologies with two leaf curl virus resistant varieties of tomato especially recommended for rainy season cultivation against the variety (Pusa Ruby) cultivated by most of the farmers during rainy season.

\section{Material and Methods}

The present study was carried out by the Krishi Vigyan Kendra, Mahamaya Nagar, C. S. Azad University of Agriculture \& Technology, Kanpur (U.P.) during rainy seasons of two consecutive years 2010-11 to 2011-12 in the farmers fields of 05 -villages of Sasni block of the district in agro-climatic zone - IV of Uttar Pradesh to 2011-12 in irrigated condition on medium soils with low to medium fertility. Each demonstration was conducted in an area of 0.1 ha and 0.1 ha area adjacent to the demonstration plot as farmer's practices i.e. prevailing cultivation practices served as local check. All 25-on farm testing trails demonstrations in 2.5 ha area was conducted. The experiment was arranged in a randomized block design (RBD) with 5 replications, farmer as replication.

The IDM technologies modules were T1(check-1) = Farmers practice (Variety-Pusa Ruby+ indiscriminate use of insecticides), T2 (technology-2) = Variety Kashi Vishesh + Seed treatment with Imidacloprid, netting of nursery, spray 4\% NSKE minimize whitefly population, TLCV and leaf miner incidence + Pre transplanting application of Imidacloprid@0.3 ml/lit in nursery protects the newly planted crop from whitefly infestation.(source of technology IIVR,Varansi,year of technology,2009-10) and T3 (technology-3) = Variety Arka Ananya + Raise Marigold (Tall African variety golden age bearing yellow and orange flowers) nursery 15-20 days before tomato nursery+ One week after germination of seeds, spray the seedlings with (Imidacloprid 200 SL@ 0.3 ml/1 or Thiomethoxam 25 WP (a) $0.3 \mathrm{~g} / \mathrm{l})+$ Apply Neem cake $250 \mathrm{~kg} /$ ha ridges at the time of preparing land + Dip the roots of seedlings (do not dip the foliage as it may cause burning of leaves) with Imidacloprid 200 SL@ 0.3 ml/1 or Thiomethoxam 25 WP@ $0.3 \mathrm{~g} / 1$ for 5 minutes. Fifteen days after planting spray Imidacloprid 200 SL@0.4ml/1 or Thiomethoxam 25 WP @ 0.3g/l for leaf curl vector (whitefly) control+ Destroy leaf curl and other virus affected plants as soon as the symptoms appear in a few plants to minimize their spread (source of technology,IIHR,Bangore, year of technology, 2009-10)

All these IDM technologies modules were used in tomato crop for leaf curl virus management. The seed sown in the raised nursery beds on 6th of June 2010-11 and 2011-12. After 25 days, these seedlings were transplanted in the experimental plots on 1st July of 2010-11 and 2011-12. The individual plot size was $15 \mathrm{~m} 2$ (3 X $5 \mathrm{~m}$ ) per treatment. Seedlings were transplanted at a spacing of 45 $\mathrm{cm}$ on ridges spaced at $45 \mathrm{~cm}$ apart, counting a total of 60 plants per plot. The experimental plots were interspaced at $1.2 \mathrm{~m}$. Each cultivar was given the same management treatments i.e. fertilization, irrigation, weeding and different IDM technologies modules against leaf curl virus disease. Compost@25 tons/ha and NPK@50:60:60 kg/ha was applied as basal dose during field preparation and additional dose of nitrogen@70 kg/ha was applied as top dressing in two equal splits at 30 and 50 days after transplanting. Irrigation was applied as and when necessary.

Normal cultural practices were adopted to raise the crops successfully. The observations in each plot every year to record the on number of fruits/cluster, fruits/plant, average fruit weight, marketable fruit yield, non-marketable fruit yield and plant stand (survivability) at harvest and The yield was recorded on plot basis. The leaf curl virus incidence and severity were recorded 75 days after transplanting. The severity was rated in 3 grades, 1 - mild symptom (light foliar yellowing), 2- moderate symptoms (light foliar yellowing, curling and slight plant stunting) and 3 -severe symptoms (very severe plant stunting, leaf size reduction, leaf curling and yellowing). The mean data for all observations over two years were pooled and statistically analyzed following standard procedure.

Materials for the Present Study was as follows

T1-Farmers practice- Variety-Pusa Ruby + indiscriminate use of insecticides

T2-Variety Kashi Vishesh + Seed treatment with Imidacloprid, netting of nursery, spray 4\% NSKE minimize whitefly population, TLCV and leaf miner incidence + Pre transplanting application of Imidacloprid (a) $0.3 \mathrm{ml} / \mathrm{lit}$ in nursery protects the newly planted crop from whitefly infestation, Source of technology,IIVR, Varanasi, 2009-10 
T3-Variety , Arka Ananya+ raise Marigold (tall African variety golden age bearing yellow and orange flowers) nursery 15-20 days before tomato nursery+ One week after germination of seeds, spray the seedlings with (Imidacloprid 200 SL@ 0.3 ml/1 or Thiomethoxam 25 WP (a) $0.3 \mathrm{~g} / \mathrm{l})+$ Apply Neem cake $250 \mathrm{~kg} / \mathrm{h}$ a ridges at the time of preparing land+ Dip the roots of seedlings (do not dip the foliage as it may cause burning of leaves) with Imidacloprid 200 SL@ 0.3 ml/l or Thiomethoxam 25 WP (a) $0.3 \mathrm{~g} / 1$ for 5 minutes. Fifteen days after planting spray Imidacloprid200 SL@0.4ml/1 or Thiomethoxam 25 WP (a) $0.3 \mathrm{~g} / 1$ for leaf curl vector (whitefly) control+ Destroy leaf curl and other virus affected plants as soon as the symptoms appear in a few plants to minimize their spread

In OFT demonstration plots, critical inputs in the form of quality seed and treatment, farm manure, balanced fertilizers and agro-chemicals were provided by KVK. For the study, assessment and refinement of different IDM technologies for suitability at local or microclimatic situation so that these technologies would be further accepted or rejected or refined as per feedback of technological and farmers. The suitable modules were assessed for large scale demonstrated among more farmers for diffusion and adoption of technology for management of leaf curl virus of tomato. The technological gap, extension gap and technology index were calculated as suggested by Samui, et al .(2000). yield

Technology gap $=$ Potential yield - Demonstration

Extension gap $=$ Demonstration yield-Farmers yield

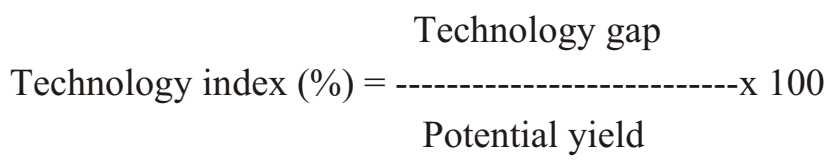

\section{Results and Discussion} Disease

Effect on Tomato yield, Growth Parameters and

\section{Tomato Fruit Yield}

The yield of tomato under different integrated leaf curl virus disease management technologies ranged from 114.2 to $274.4 \mathrm{q} / \mathrm{ha}$ with highest average yield $270.9 \mathrm{q} / \mathrm{ha}$. The cultivation of tomato with leaf curl management technologies, the yield ranged from with mean average 225.2 to $229.1 \mathrm{q} / \mathrm{ha}$, ( average mean $(227.1 \mathrm{q} / \mathrm{ha})$ with leaf curl virus resistant variety Kashi Vishesh with IDM technology-2, while in technology-3 with resistant variety Arka Ananya 267.5 to $274.4 \mathrm{q} /$ ha with an average mean yield (270.9 q/ha) during 2010-11 to 2011-12 (Table-1) as against a yield ranged $114.2 \mathrm{q} / \mathrm{h}$ a to $116.2 \mathrm{q} / \mathrm{ha}$ with a mean of $115.2 \mathrm{q} / \mathrm{ha}$ recorded under farmer's practices (technology-1, local check) in an average mean of both the years. This finding is in corroboration with the findings of Dharmatti et al.2008, Rakib et al.2011, Govindappa et al.(2013), Mishra and Lal (1998) and Rida et al., (2002)and Manoj and Raghav (1998).

The additional tomato fruit yield under technology-2 over local check ranged from 111 to $113 \mathrm{q} /$ ha with a mean of $112 \mathrm{q} / \mathrm{ha}$. In comparison to local check there was an increase of $94.1 \%$ in yield of tomato with technology 1 in both the years' means. The increased tomato fruit yield with variety Kashi Vishesh + IDM technology-2 was mainly because of use improved leaf curl virus resistant variety and IDM technology. While the additional yield of tomato fruit over local checked ranged from 153 to 158 $\mathrm{q} / \mathrm{ha}$ with a mean of $156 \mathrm{q} / \mathrm{ha}$ in leaf curl virus resistant variety Arka Ananya + IDM technology-3 for leaf curl virus management in mean of both the years. The increased in comparison to over farmer practice was $135.1 \%$ in both the years mean. The overall performance among technologies, the highest yield and increased over farmers check was in Technology-2. This finding is in corroboration with the findings of Govindappa et al.(2013), Mishra and Lal (1998) and Rida et al., (2002)and Manoj and Raghav (1998)

\section{Effect on Growth Parameters of Tomato}

Data on other parameters i.e. number of fruits/plant and weight of fruit (gm) of tomato was also found increased in both the technological intervention over farmers, practices (Table 1). The average number of tomato fruits 47.6 and 59.2 with an increased $6.9 \%$ and $32.8 \%$ in an average mean of both the years respectively, in technology-2 and technology-3 over farmer practices 44.5 . The average mean weight of fruit was also recorded an increased trend 60.85 (g) and $69.15(\mathrm{~g})$ with increased $24.9 \%$ and $41.95 \%$ over farmers practices $(48.7 \mathrm{~g})$. The highest performance in all parameters of tomato was recorded on technological intervention-2 (T-3). This finding is in corroboration with the findings of Mishra and Lal (1998) and Rida et al., (2002)and Manoj and Raghav (1998). 


\section{Decreased in Leaf Curl Virus Disease (\%) of Tomato}

The significant data on highest decreased in leaf curl virus of tomato were recorded $89.5 \%$ and $96.7 \%$ in both the years mean over farmers' practices, respectively in technology-2 and technology-3. The incidence of leaf curl virus was recorded least $2.2 \%$ in technology- 2 while $7.05 \%$ in technology- 1 while disease incidence was highest $67.6 \%$ in farmers practice on the mean basis of both the consecutive year (Table 1).

Table: 1 Effect of different technologies of management for leaf curl virus disease in tomato on yield $(q / h a)$, decreased in disease incidence, No. of fruits/plant and weight of fruit/plant at farmers, fields during two consecutive years (2010-11 to 2011-12).

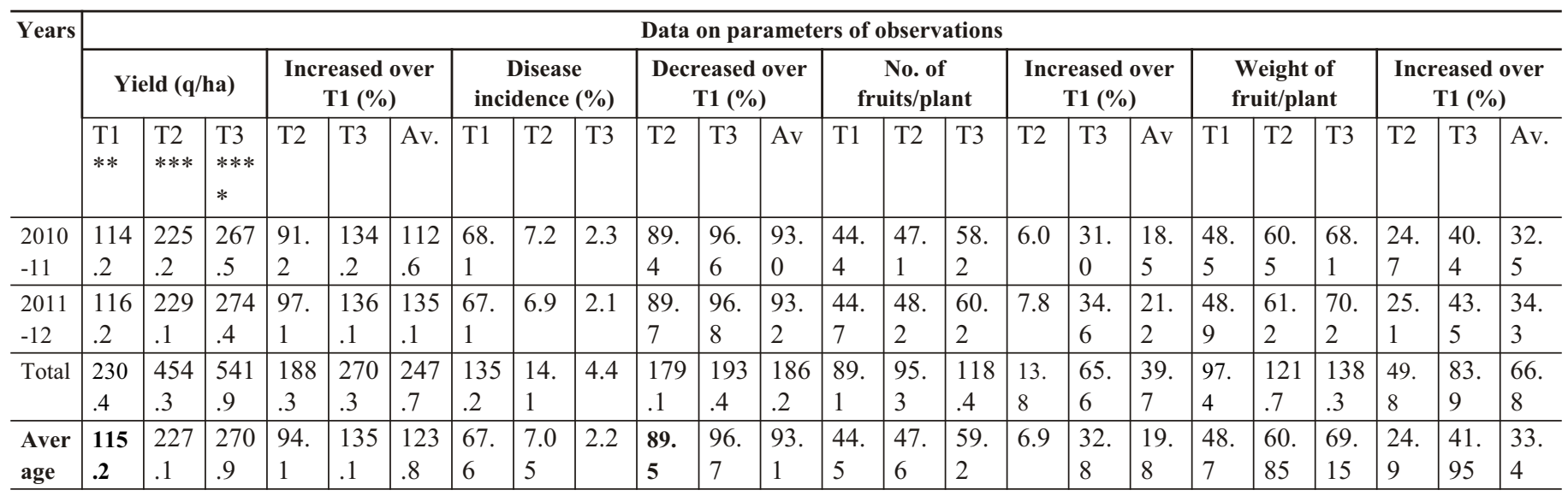

Note $=* * \mathrm{~T} 1=($ Farmers, practice $), * * * \mathrm{~T} 2=\mathrm{Technology}-1, * * * * \mathrm{~T} 3=\mathrm{Technology}-2, \mathrm{AV}=$ Average

\section{Economics Analysis}

\section{Net Return}

The economic viability of improved technologies over traditional farmer's practices was calculated depending on prevailing prices of inputs and outputs costs (Table-2). It was found that cost of production of tomato varied from Rs.39000 and 40000 to 42000 and 43000/ha with an average of Rs.39500/ha and Rs. 42500/ha of improved technologies as against the variation in cost of production from Rs.31000 to 32000/ha with an average of Rs.31500/ha in local check in both the years. The improved production technologies registered an additional cost of production ranging from Rs. 8000/ha and 11000 with a mean of Rs.8000/ha and 11000/ha over local check, respectively, technology-2 and technology-3. The additional cost incurred in the improved technologies as compared to farmer's practices was mainly due to more costs involved in inputs of technologies. Cultivation of tomato under improved technologies gave higher net return ranged from Rs. 153740 to 167825 /ha, with a mean value of Rs.160783/ha and Rs. 183050 to 201500/ha, with a mean value of Rs. 192275/ha as compared to local check mean value of Rs. 80395/ha. There was an additional net return of Rs. 106210 to 117550 /ha and Rs.91555 to 100712/ha in the years respectively, technology -2 and technology-3 under demonstration plots. The improved technologies also gave higher benefit cost ratio 4.2 to 4.7 compared to 2.6 under local check in the corresponding seasons in technology-2 and 3, respectively. This may be due to higher yields obtained under improved technologies compared to local check (farmers practice). This finding is in corroboration with the findings of Dharmatti et al.2008, Rakib et al.2011, Govindappa et al.(2013), Mishra and Lal (1998) and Rida et al., (2002)and Manoj and Raghav (1998)

The results from the current study clearly brought out the higher potential yield and leaf curl disease resistant varieties as well as improved integrated disease management technologies in enhancing tomato production, reducing highest incidence of leaf curl disease and economic grains in Mahamaya Nagar district condition of Uttar Pradesh. 
Table: 2 Economical analysis of cost of cultivation, gross cost, net return (Rs/ha) and cost benefit ratio of different technological modules for management of leaf curl virus disease in tomato at farmers, fields during two consecutive years (2010-11 to 2011-12).

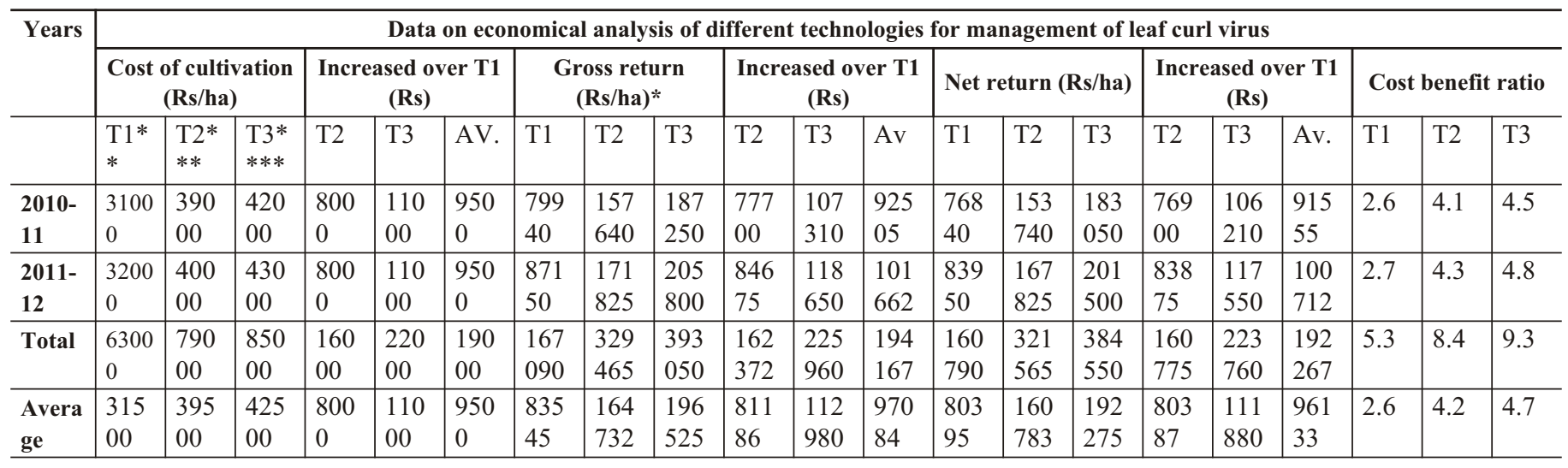

*Sale rate of tomato@ Rs. 700/quintal (2010-11), Rs. 750 (2011-12), ** T1= (Farmers, practice), ** T2= Technology-1, $* * *$ T3 $=$ Technology $-2, \mathrm{AV}=$ Average,

\section{Technology Gap}

The technology gap in the demonstration tomato yield over potential yield were $303.7 \mathrm{q} / \mathrm{ha}$ in Kashi Vishesh and 498.3 $\mathrm{q} /$ ha in Arka Ananya with an average on both the years $401 \mathrm{q} / \mathrm{ha}$ in both the varieties and its respective technologies for leaf curl virus management in tomato (Table 3). The technological gap may be attributed to the dissimilarity in the soil fertility status and weather conditions

\section{Extension Gap}

The highest extension gap of $135.5 \mathrm{q} / \mathrm{ha}$ was recorded in tomato variety Arka Ananya and the lowest was observed in 132.1 q/ha in variety Kashi Vishesh with its IDM. This emphasized the need to educate the farmers through various means for the adoption of improved tomato production technologies to reverse this trend of wide extension gap. More and more use of latest production and IDM technologies with high yielding and resistant varieties will subsequently change this alarming trend of galloping extension gap. The new technologies will eventually lead to the farmers to discontinue the old technology and to adopt new technology (Table 3).

\section{Technology Index}

The technology index shows the feasibility of the evolved technology at the farmer's fields and the lower the value of technology index more is the feasibility of the technology. The average technology index was 60.8 per cent, while $66.4 \%$ maximum technology index was in technology-3 with Arka Ananya during 2010-11 to 2011-12 (Table 3).

Table: 3. Extension gap (q/ha), Technology gap(q/ha) and technology index $(\%)$ on demonstration of IDM intervention

\begin{tabular}{|c|c|c|c|c|c|c|c|c|c|}
\hline \multirow{3}{*}{ Year } & \multirow{3}{*}{ Varieties } & \multicolumn{5}{|c|}{ Yield (q/ha) } & \multirow{3}{*}{$\begin{array}{l}\text { Extension } \\
\text { gap }(q / \text { ha) }\end{array}$} & \multirow{3}{*}{$\begin{array}{c}\text { Technology } \\
\text { gap (q/ha) }\end{array}$} & \multirow{3}{*}{$\begin{array}{l}\text { Technology } \\
\text { Index (\%) }\end{array}$} \\
\hline & & \multirow{2}{*}{ Potential } & \multicolumn{3}{|c|}{ Improved technology } & \multirow{2}{*}{\begin{tabular}{|l} 
Local Check \\
Pusa Ruby*
\end{tabular}} & & & \\
\hline & & & $\mathrm{T} 2$ & T3 & Average & & & & \\
\hline 2011-12 & $\begin{array}{l}\text { Arka } \\
\text { Ananya }\end{array}$ & 750 & 229.1 & 274.4 & 251.7 & 116.2 & 135.5 & 498.3 & 66.4 \\
\hline
\end{tabular}

" Potential yield of Pusa Ruby (130 q/ha) 


\section{Conclusion}

The results were found highly significant increased in yield and growth attributes of tomato on resistant varieties of leaf curl virus with integrated disease management technologies and reduced disease incidence as comparison to farmer practices. The high yield and disease resistant varieties with disease management technologies were found the main factors to gave the high achievement on tomato cultivation while farmers were unaware about these varieties and disease management practices. Farmers were convinced due to performance of technologies and accepted the ones but farmers want availability of new technologies inputs timely at local market. These technologies further could be taken under front line demonstration programme for large scale adoption horizontal and vertical spread among tomato grower of the district.

\section{References}

Anon., (2013). Indian Horticulture Database, Chapter 02, Tomato, $177-185 \mathrm{pp}$

Dharmatti, P. R., Patil, R. V. and Mannikeri, I. M. (2008). A New High Acid Content Tomato cv. DMT-2 for North Karnataka, Karnataka J. Agric. Sci.,21( 3) : (421-423)

Govindappa, M.R. Bhemanna, M., Arunkumar Hosmani and V.N. Ghante (2013). Bio-efficacy of newer insecticides against tomato leaf curl disease and its vector disease and its vector whitefly (Bemisia tabaci) in tomato. International Journal of Applied Biology and Pharmaceutical Technology 3(2) pp 226-231.

Harrison, B.D., Muniyappa, V., Swanson, M.M., Roberts, I.M. and Robinson, D.J., (1991), Recognition and differentiation of seven whitefly transmitted geminiviruses in India and their relation to African cassava mosaic and Thailand mungbean yellow mosaic virus. Ann. Appl. Biol., 118: 229-308.
Kallo, G., S. N. G. Chaurasia, S. Major and M. Singh 1998. Stability analysis in tomato. Vegetable Research, Ghandi Nagar, India. Vegetable Sci., 25 (1): 81-84.

Manoj, R. and M. Raghav 1998. Performance of F1 hybrids and high yielding varieties of tomato under mid-west plains of Uttar Pradesh. Prog. Hort., 30 (3): 194-197.

Mishra, Y. K. and S. D. Lal 1998. Studies on varietal performance of tomato under the agro climatic conditions of U. P. hills. Prog. Hort., 30 (3): 153-157.

Muniyappa, V. and Veeresh, G.K., (1984). Plant virus diseases transmitted by whiteflies in Karnataka. Proc. Indian Acad. Sc., (Animal Sci.). 93: 397-406.

Muniyappa, V., (1980), Whiteflies. In: Vectors of Plant Pathogen (Eds K.F. Harris and K Maramorosch) 39-85, Academic press, New York.

Muniyappa, V., Venkatesh, H.M., Ramappa, H.K., Kulkarni, R.S., Zeidan, M., Tarba, C.Y., Ghanim, M. and Czosnek, H., (2000). Tomato leaf curl virus from Bangalore (ToLCV Ban4): sequence comparison with Indian ToLCV isolates, detection in plants and insects and vector relationships. Arch. Virol, 145 : 1583- 1598.

Rakib A. Al-ani, Mustafa A. Adhab*, Samir A. H. Hamad and Saber N. H. Diwan(2011). African Journal of Agricultural Research Vol. 6(22), pp. 5149-5155, 12 October, 2011

Rida, A. S., A. A. Muhammad, I. E. Ereifij and A. Hussain 2002. Evaluation of thirteen open pollinated cultivars and three hybrids of tomato (Lycopersicon esculentum Mill.) for yield, physiological disorders, seed production and vegetative growth. Pak. J. Agric. Res., 17 (3): 290- 296.

Saikia, A.K. and Muniyappa, V., (1989). Epidemiology and control of tomato leaf curl virus in southern India. Trop. Agric., 66: 350-354.

Samui, S.K, Maitra S, Ro,y D.K, Mondal, A.K and Saha, D. (2000). Evaluation on front line demonstration on groundnut (Arachis hypogea L.). J. of Indian Soc. of Coastal Agriculture Research 18: 180-183.

Sastry, K.S. and Singh, S.J., (1973). Assessment of losses in tomato by tomato leaf curl virus. Indian J. Mycol. P1. Pathol., 3:50-54. 